\title{
Penerapan Metode Simple Additive Weighting Pada Sistem Pendukung Keputusan Pengangkatan Karyawan Berbasis Web
}

\author{
Siti Ernawati ${ }^{1}$, Risa Wati ${ }^{2}$ \\ ${ }^{1}$ STMIK Nusa Mandiri Jakarta \\ e-mail: siti.ste@ nusamandiri.ac.id \\ ${ }^{2}$ Universitas Bina Sarana Informatika \\ e-mail: risawati.rwx@bsi.ac.id
}

\begin{abstract}
The success or failure of a company depends on the human resources in the company. The quality of every human resource is needed to improve performance productivity. The process of appointing permanent employees is something that is often done by companies, one of the reasons is the company's appreciation of employee performance. For this reason, the process of appointing employees is more professional, so a decision support system is needed to assist in selecting employees who deserve to be appointed as permanent employees. The method will be applied in this research is simple additive weighting (SAW). SAW method is selected because it is very simple, can determine the value of weight then determine the ranking of the results of normalization. There are ten criteria and weights for each of the criteria used in this research. The purpose of this research is to design and create a web based information system as a tool for decision making in the process of appointment employees. It is hoped that this information system will benefit for the company so hat the employee appointment process do optimally and the time is more efficient.
\end{abstract}

Keywords: Appointment of Employees, Decision Support System, Simple Additive Weighting

\section{PENDAHULUAN}

Faktor terpenting dalam kegiatan manajemen sebuah perusahaan yang sedang berjalan adalah sumber daya manusia. Sumber daya manusia merupakan aset utama dalam sebuah perusahaan. Tumbuh kembang perusahaan tergantung dari sumber daya manusia yang ada didalamnya. Semakin berkualitas sumber daya manusia yang dimiliki perusahaan, semakin mudah bagi perusahaan untuk mencapai target dan tujuan yang akan diraih. Proses pengangkatan karyawan tetap merupakan hal yang sering sekali dilakukan oleh sebuah perusahaan. Pengangkatan karyawan dilakukan karena beberapa hal, salah satu diantaranya adalah sebagai apresiasi perusahaan terhadap kinerja karyawan dan menandakan bahwa perusahaan mentaati peraturan pemerintah tentang undang-undang ketenagakerjaan nomor 13 tahun 2013 yaitu jangka waktu maksimal masa percobaan kinerja karyawan selama tiga bulan, dalam masa tersebut karyawan diberikan penilaian layak atau tidak untuk menjadi karyawan tetap dalam sebuah perusahaan.

Dalam proses pengangkatan karyawan biasanya diawali dengan penilaian terhadap kinerja dari setiap karyawan selama bekerja di perusahaan. Proses pengangkatan karyawan tetap dijadikan sebagai bahan evaluasi kinerja. Dalam setiap evaluasi biasanya perusahaan mempertimbangkan beberapa kriteria sebagai bahan penilaian. Kriteria yang dipertimbangkan tergantung dari kebutuhan perusahaan untuk mengukur apakah karyawan tersebut layak untuk diangkat menjadi karyawan tetap, promosi golongan, dimutasi atau penugasan tidak di lanjutkan. Tetapi beberapa perusahaan biasanya mempunyai lebih banyak kriteria yang dijadikan bahan pertimbangan untuk pengangkatan karyawan tetap. Banyaknya kriteria yang dijadikan bahan penilaian bertujuan agar perusahaan tidak salah memilih karyawan yang sangat berkualitas untuk bergabung di perusahaannya. Banyaknya data karyawan dalam perusahaan dan banyaknya kriteria yang dibutuhkan dalam penilaian terkadang menjadi masalah bagi bagian kepegawaian atau HRD. Mereka merasa kesulitan dalam menentukan karyawan mana yang layak untuk dijadikan karyawan tetap dalam sebuah perusahaan.

Terdapat beberapa penelitian terdahulu mengenai sistem pendukung keputusan yang pernah dilakukan dalam memecahkan masalah pengangkatan karyawan tetap. Penelitian yang berjudul implementasi sistem keputusan pengangkatan karyawan tetap PT. Imanuel surya Utama menggunakan metode SAW, dalam penelitian ini mengangkat kasus yaitu mencari alternatif terbaik berdasarkan kriteria yang telah ditentukan dengan menggunakan metode SAW (Simple Additive Weighting). Penelitian ini dilakukan dengan mencari nilai bobot dari setiap atribut-atribut 
yang akan digunakan, langkah selanjutnya kemudian melakukan proses perangkingan untuk menentukan nilai alternatif yang optimal (Wahyudi et al., 2015)

Penelitian berjudul sistem pendukung keputusan menentukan kelayakan pengangkatan karyawan tetap menggunakan metode analytic hierarchy process dan weighted product. Penelitian ini memanfaatkan kemajuan tekonologi informasi dan komunikasi khususnya sistem pendukung keputusan yang diharapkan dapat membantu bagian kepegawaian untuk pengambilan keputusan dalam menentukan pegawai tetap (Saepudin, Abdillah, \& Yuniarti, 2017). Berdasarkan penelitian-penelitian terdahulu maka dibangun sebuah sistem pendukung keputusan dalam menentukan kelayakan pengangkatan karyawan tetap dengan menggunakan beberapa kriteria. Metode yang dalam penelitian ini menggunakan metode simple additive weighting (SAW). Metode simple additive weighting (SAW) merupakan metode yang sederhana (Turban, Aronson, \& Liang, 2007) dan Metode SAW merupakan metode yang banyak digunakan dalam pengambilan keputusan yang memiliki banyak atribut (Sari, Kartini, \& Muliadi, 2018). Manfaat dari penelitian ini adalah sebagai bahan pertimbangan bagi manajerial perusahaan dalam mengambil keputusan untuk menentukan karyawan yang layak dijadikan karyawan tetap. Tujuan dari penelitian ini adalah merancang dan membuat sistem yang lebih baik dari sistem yang sebelumnya untuk menentukan karyawan yang layak diangkat sebagai karyawan tetap, dimana sistem sebelumnya masih bersifat manual dengan menerapkan metode simple additive weighting dan mengimplementasikannya dalam bentuk sistem informasi berbasis web. Diharapkan sistem informasi ini dapat bermanfaat untuk perusahaan agar proses pengangkatan karyawan dilakukan dengan lebih optimal dan waktu yang diperlukan menjadi lebih efisien.

\section{METODOLOGI PENELITIAN}

\section{DSS (Decision Support System)}

Decision Support System merupakan sistem yang ditujukan untuk mendukung pengambil keputusan manajerial dalam situasi keputusan semiterstruktur. Decision Support System dimaksudkan sebagai tambahan bagi para pembuat keputusan untuk memperluas kemampuan mereka tetapi tidak untuk menggantikan penilaian para pembuat keputusan. DSS biasanya dibangun untuk mendukung solusi dari masalah tertentu atau untuk mengevaluasi peluang. Para pembuat keputusan diarahkan pada penilaian atau keputusan yang tidak sepenuhnya hanya didukung oleh algoritma, tetapi mereka lebih menyukai Decision Support System tersebut berbasis komputer yang beroperasi secara online dan memiliki kemampuan untuk menghasilkan output berupa grafis (Turban et al., 2007).
2. SAW (Simple Additive Weighting)

Metode SAW adalah salah satu Metode MADM yang paling banyak digunakan. Metode ini sederhana dan merupakan dasar dari sebagian besar Metode MADM seperti AHP dan PROMETHEE yang mendapat manfaat dari properti (sifat/ciri) tambahan untuk menghitung skor akhir alternatif. Dalam Metode SAW, skor akhir dari setiap alternatif dihitung dan mereka diberi peringkat (Alinezhad, Amini, \& Alinezhad, 2009). Metode Simple Additive Weighting sering juga dikenal dengan istilah metode penjumlahan berbobot. Konsep dasar metode SAW ini adalah mencari penjumlahan terbobot dari rating kinerja pada setiap alternatif pada semua atribut (Sari et al., 2018).

Perhitungan matrik dalam metode SAW dibagi menjadi dua yaitu perhitungan atribut profit dan atribut cost. SAW dapat digunakan jika semua kriteria yang dimaksimalkan. Ini merupakan kelemahan dari metode SAW, meskipun kriteria minimalisasi dapat dengan mudah dikonversi ke kriteria maksimal dengan rumus:

a. Atribut Profit (Jika nilai terbesar adalah nilai yang terbaik)

$\bar{r}_{i j}=\frac{\min _{i j} r_{i j}}{r_{i j}}$.

Keterangan :

$$
\begin{aligned}
& \bar{r}_{i j}=\text { Nilai yang dikonversi/normalisasi } \\
& r_{i j}=\text { Nilai kriteria } \\
& \min _{j} r_{i j}=\text { Nilai terkecil dari setiap kriteria }
\end{aligned}
$$

Normalisasi (atau transformasi) dari data awal digunakan, sehingga nilai kriteria terbaik (yang terbesar untuk kriteria pemaksimalan dan yang terkecil untuk kriteria peminimalan) akan mendapatkan nilai terbesar setara dengan kesatuan. Formula transformasi yang digunakan untuk memaksimalkan kriteria adalah sebagai berikut:

b.

tribut Cost (Jika nilai terkecil adalah nilai yang terbaik)

$\bar{r}_{i j}=\frac{r_{i j j}}{\max _{\bar{i}} r_{i j}}$

Keterangan :

$\bar{r}_{i j}=$ Nilai yang dikonversi/normalisasi

$r_{\mathrm{i} j}=$ Nilai kriteria 
$\max _{j} r_{\mathrm{i} j}=$ Nilai terbesar dari setiap kriteria

c.

enentukan rangking untuk setiap alternatif

$S_{j}=\sum_{i=1}^{m} \omega_{i \xi_{i j}}$

Keterangan :

$S_{j}=$ Rangking untuk setiap alternatif

$\omega_{\mathrm{i}}=$ Nilai bobot dari setiap kriteria

$\tilde{r}_{\mathrm{ij}}=$ Nilai rating kinerja ternormalisasi

Nilai $\mathrm{Sj}$ yang lebih besar mengindikasikan bahwa alternatif Ai lebih terpilih.

\section{HASIL DAN PEMBAHASAN}

1. Analisa Masalah

Setelah kontrak masa kerja karyawan berakhir, perusahaan atau instansi mempunyai kewajiban untuk membuat sebuah keputusan mengenai status karyawan tersebut apakah karyawan tersebut layak menjadi karyawan tetap atau tidak. Perusahaan akan melakukan proses penyeleksian terhadap karyawan tersebut sesuai dengan ketentuan dan persyaratan menjadi karyawan tetap pada sebuah perusahaan. Dalam penelitian ini akan diuraikan bagaimana proses dalam menentukan status karyawan kontrak tersebut diangkat menjadi karyawan tetap atau tidak. Dalam proses penyeleksian ini peneliti menggunakan metode Simple Additive Weighting (SAW) dan akan membuatkan sebuah aplikasi berbasis website untuk proses penyeleksian pengangkatan karyawan tetap.

2. Perancangan Sistem Menggunakan Metode SAW Penelitian yang dilakukan dengan model eksperimen dalam bentuk sistem penunjang keputusan untuk menentukan kelayakan pengangkatan karyawan tetap menggunakan metode Simple Additive Weighting (SAW). Langkah-langkah dalam penelitian ini adalah melakukan analisis dengan cara:

a. Mengumpulkan data yang berkaitan dengan objek penelitian.

Data yang digunakan dalam penelitian ini adalah data karyawan dan hasil evaluasi dari masing-masing karyawan yang ada pada sebuah perusahaan yang nantinya hasil evaluasi tersebut akan digunakan untuk bahan pertimbangan perusahaan untuk menentukan apakah karyawan tersebut diangkat menjadi karyawan tetap, penugasan dilanjutkan atau penugasan tidak di lanjutkan.

b. Menentukan kriteria yang akan dijadikan acuan untuk pengambilan keputusan dalam menentukan kelayakan pengangkatan karyawan tetap.
Ada beberapa kriteria dan bobot yang digunakan untuk melakukan penilaian dalam penelitian ini yaitu:

Tabel 1. Kriteria Pengangkatan Karyawan Tetap

\begin{tabular}{lll}
\hline & \multicolumn{1}{c}{ Kriteria } & Bobot \\
\hline K1 & Semangat Untuk Berprestasi & $5 \%$ \\
K2 & Kompetensi Pada Bidang Tugas & $10 \%$ \\
K3 & Kecepatan Menyelesaikan Tugas & $10 \%$ \\
K4 & Kualitas Hasil Pekerjaan & $15 \%$ \\
K5 & Kerjasama Team & $15 \%$ \\
K6 & Kepemimpinan & $5 \%$ \\
K7 & Kedisiplinan & $15 \%$ \\
K8 & Kepatuhan Terhadap Atasan & $10 \%$ \\
K9 & Upaya Meningkatkan Kemampuan & $5 \%$ \\
K10 & Kegigihan / Keuletan & $10 \%$ \\
\hline Jumlah & $100 \%$ \\
\hline \multicolumn{2}{l}{ Sumber: Hasil Penelitian (2019) }
\end{tabular}

Nilai Alternatif :

Tabel 2. Alternatif Pengangkatan Karyawan Tetap

\begin{tabular}{ll}
\hline Alternatif & Keterangan \\
\hline A1 & Karyawan Tetap \\
A2 & Penugasan di Lanjutkan \\
A3 & Penugasan Tidak di Lanjutkan \\
\hline
\end{tabular}

Sumber: Hasil Penelitian (2019)

c. Rating kecocokan dari setiap kriteria

Tabel 3. Rating Kecocokan dari Setiap Kriteria

\begin{tabular}{rrrrrrrrrrr}
\hline \multirow{2}{*}{ NIK } & \multicolumn{10}{c}{ Kriteria } \\
\cline { 2 - 10 } & K1 & K2 & K3 & K4 & K5 & K6 & K7 & K8 & K9 & \multicolumn{1}{l}{ K10 } \\
\hline 4005 & 5 & 7 & 9 & 8 & 5 & 8 & 7 & 8 & 7 & 8 \\
4006 & 9 & 9 & 8 & 8 & 8 & 9 & 9 & 8 & 9 & 9 \\
4007 & 5 & 6 & 7 & 7 & 6 & 5 & 8 & 7 & 7 & 5 \\
4008 & 7 & 8 & 8 & 9 & 5 & 6 & 8 & 10 & 7 & 10 \\
4009 & 6 & 8 & 8 & 7 & 5 & 6 & 8 & 7 & 8 & 10 \\
\hline
\end{tabular}

Sumber: Hasil Penelitian (2019)

Pembentukan matrik berdasarkan data diatas adalah

$A=\left(\begin{array}{cccccccccc}5 & 7 & 9 & 8 & 5 & 8 & 7 & 8 & 7 & 8 \\ 9 & 9 & 8 & 8 & 8 & 9 & 9 & 8 & 9 & 9 \\ 5 & 6 & 7 & 7 & 6 & 5 & 8 & 7 & 7 & 5 \\ 7 & 8 & 8 & 9 & 5 & 6 & 8 & 10 & 7 & 10 \\ 6 & 8 & 8 & 7 & 5 & 6 & 8 & 7 & 8 & 10\end{array}\right)$

d. Menghitungnormalisasi

Untuk menghitung normalisasi berdasarkan rating kecocokan diatas sebagai berikut:

$$
\begin{array}{ll}
r_{1_{1,1}}=\frac{5}{9}=0.56 & r_{1,6}=\frac{8}{9}=0.89 \\
r_{1_{1,2}}=\frac{7}{9}=0.78 & r_{1,7}=\frac{7}{9}=0.78 \\
r_{1,9}=\frac{9}{9}=1.00 & r_{1,9}=\frac{8}{10}=0.80 \\
r_{1,4}=\frac{8}{9}=0.89 & r_{1,9}=\frac{7}{9}=0.78 \\
r_{1,5}=\frac{8}{8}=0.63 & r_{1,10}=\frac{8}{10}=0.80
\end{array}
$$


Hasil perhitungan normalisasi dibuat dalam matriks normalisasi:

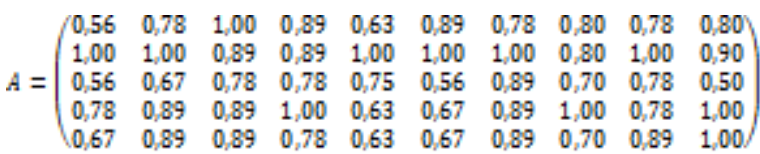

e. Pemberian nilai bobot untuk setiap kriteria yang telah ditentukan

Nilai bobot yang diberikan sesuai dengan nilai yang telah ditentukan oleh setiap perusahaan untuk menilai setiap karyawannya. Nilai bobot yang berlaku dalam penelitian ini adalah:

\section{$\omega=\left[\begin{array}{llllllllll}0,05 & 0,10 & 0,10 & 0,15 & 0,15 & 0,05 & 0,15 & 0,10 & 0,05 & 0,10\end{array}\right]$}

f. Perangkingan

Perangkingan menggunakan bobot yang telah ditentukan sebelumnya. Hasil yang diperoleh dari perangkingan adalah nilai normalisasi yang dikalikan dengan nilai bobot setiap kriteria.

Tabel 4. Hasil Perangkingan

\begin{tabular}{cccccccccccc}
\hline $\mathrm{NI}$ & $\mathrm{K}$ & $\mathrm{K}$ & $\mathrm{K}$ & $\mathrm{K}$ & $\mathrm{K}$ & $\mathrm{K}$ & $\mathrm{K}$ & $\mathrm{K}$ & $\mathrm{K}$ & $\mathrm{K}$ & \multirow{2}{*}{$\omega$} \\
$\mathrm{K}$ & 1 & 2 & 3 & 4 & 5 & 6 & 7 & 8 & 9 & 10 & \\
\hline 40 & 1. & 1. & 0. & 0. & 1. & 1. & 1. & 0. & 1. & 0. & 0. \\
06 & 00 & 00 & 89 & 89 & 00 & 00 & 00 & 80 & 00 & 90 & 94 \\
40 & 0. & 0. & 0. & 1. & 0. & 0. & 0. & 1. & 0. & 1. & 0. \\
08 & 78 & 89 & 89 & 00 & 63 & 67 & 89 & 00 & 78 & 00 & 87 \\
40 & 0. & 0. & 0. & 0. & 0. & 0. & 0. & 0. & 0. & 1. & 0. \\
09 & 67 & 89 & 89 & 78 & 63 & 67 & 89 & 70 & 89 & 00 & 80 \\
40 & 0. & 0. & 1. & 0. & 0. & 0. & 0. & 0. & 0. & 0. & 0. \\
05 & 56 & 78 & 00 & 89 & 63 & 89 & 78 & 80 & 78 & 80 & 79 \\
40 & 0. & 0. & 0. & 0. & 0. & 0. & 0. & 0. & 0. & 0. & 0. \\
07 & 56 & 67 & 78 & 78 & 75 & 56 & 89 & 70 & 78 & 50 & 72 \\
\hline
\end{tabular}

Sumber: Hasil Penelitian (2019)

Tabel 5. Keputusan dari hasil perangkingan yang telah dilakukan

\begin{tabular}{ccrl}
\hline Perangkingan & NIK & \multicolumn{1}{c}{$\omega$} & Keputusan \\
\hline 1 & 4006 & 0.94 & Karyawan Tetap \\
2 & 4008 & 0.87 & Penugasan Dilanjutkan \\
3 & 4009 & 0.8 & Penugasan Dilanjutkan \\
4 & 4005 & 0.79 & Penugasan Dilanjutkan \\
5 & 4007 & 0.72 & Penugasan Tidak Dilanjutkan \\
\hline
\end{tabular}

Sumber: Hasil Penelitian (2019)

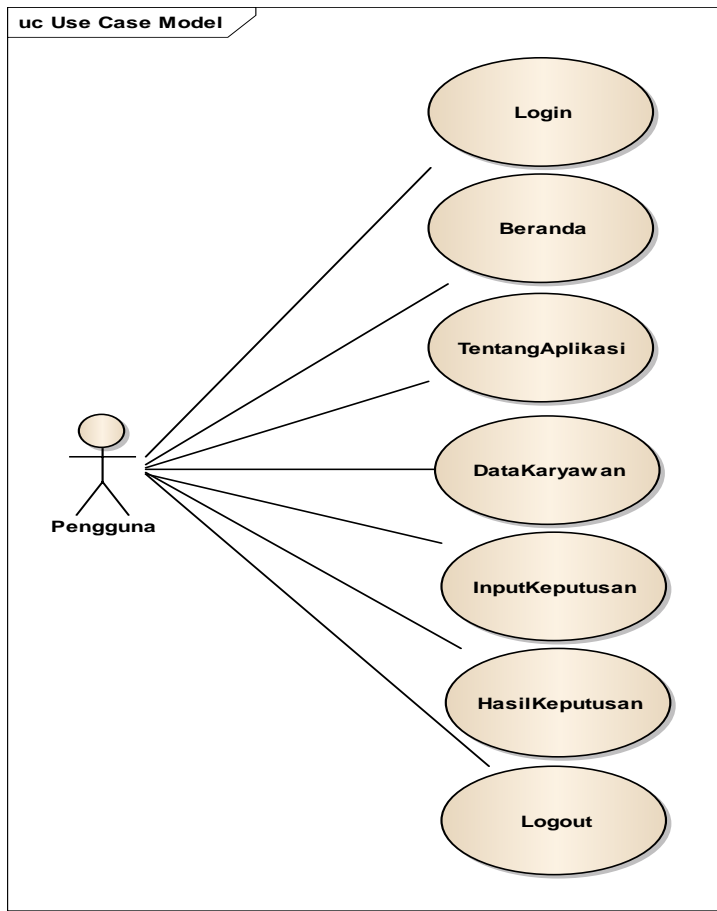

Sumber: Hasil Penelitian (2019)

Gambar 1. Use Case Diagram SPK Pengangkatan Karyawan Tetap

b. Activity Diagram

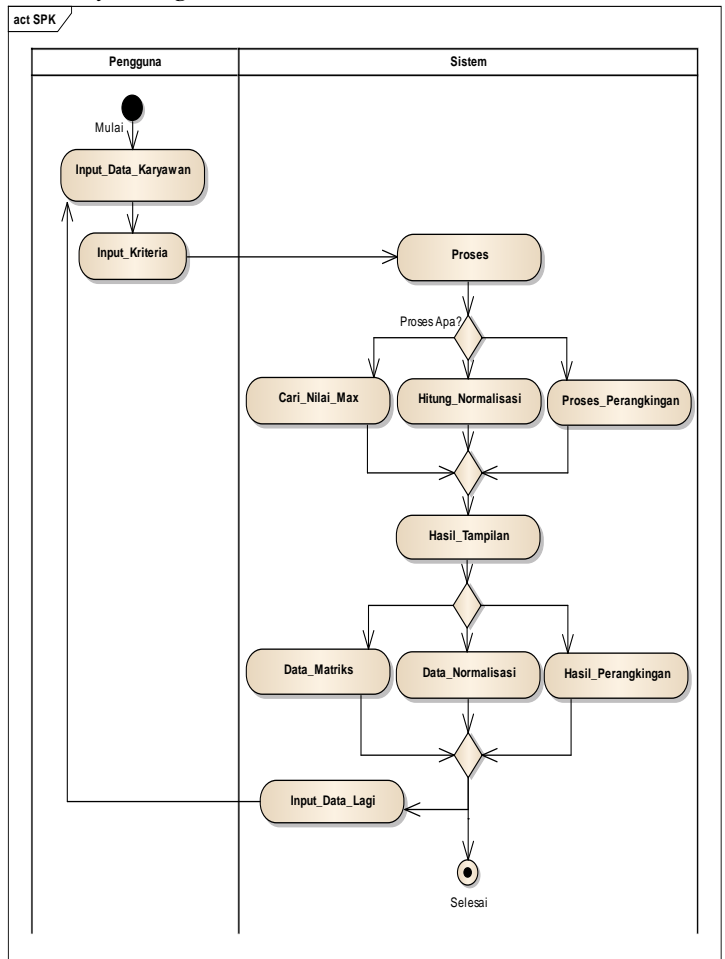

Sumber: Hasil Penelitian (2019)

Gambar 2. Activity Diagram SPK Pengangkatan

c. ERD

3. Perancangan Sistem Informasi

a. Usecase Diagram 


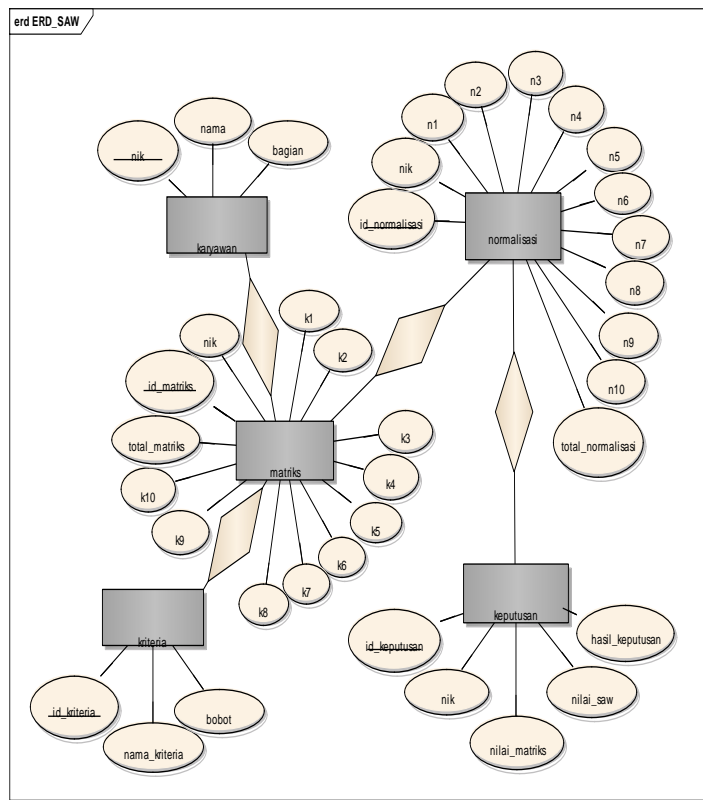

Sumber: Hasil Penelitian (2019)

Gambar 3. ERD SPK Pengangkatan Karyawan Tetap

d. User Interface

1) Halaman Login User

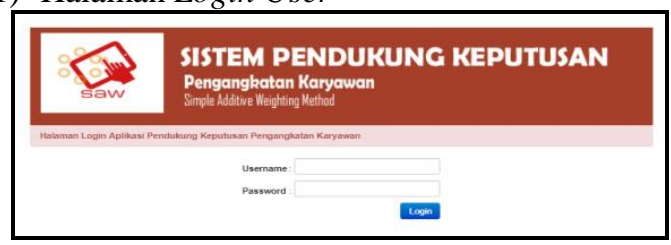

Sumber: Hasil Penelitian (2019)

Gambar 4. Halaman Login User

2) Halaman Beranda

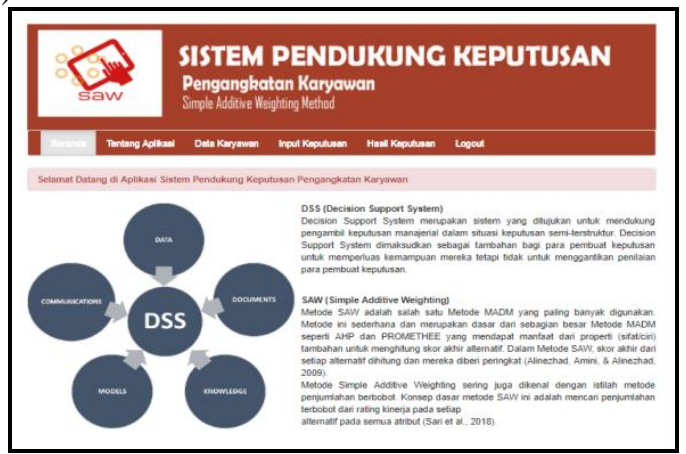

Sumber: Hasil Penelitian (2019)

Gambar 5. Halaman Beranda

3) Halaman Data Karyawan

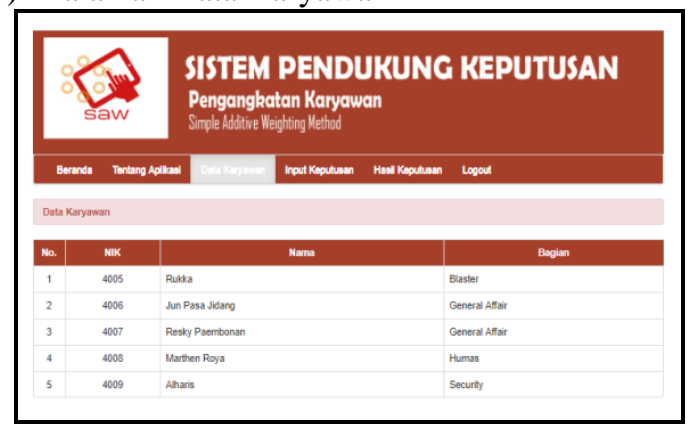

Sumber: Hasil Penelitian (2019)

Gambar 6. Halaman Data Karyawan

4) Halaman Input Keputusan

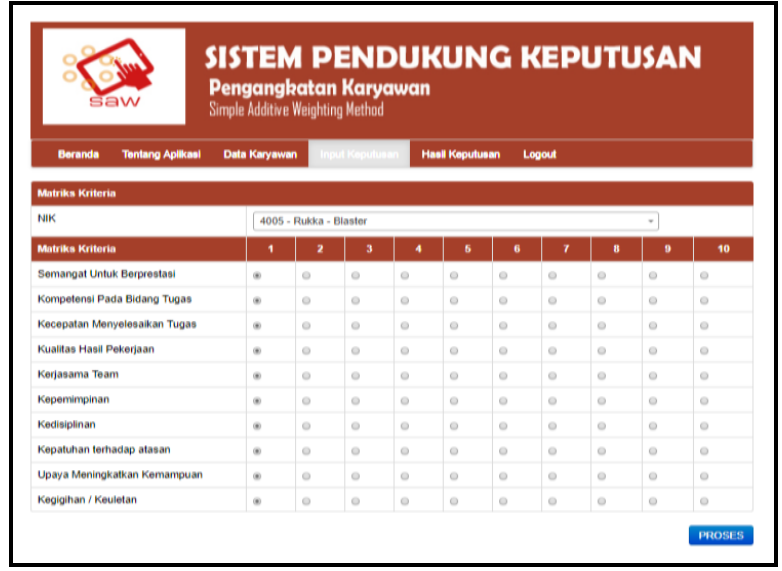

Sumber: Hasil Penelitian (2019)

Gambar 7. Halaman Input Keputusan

5) Halaman Hasil Keputusan

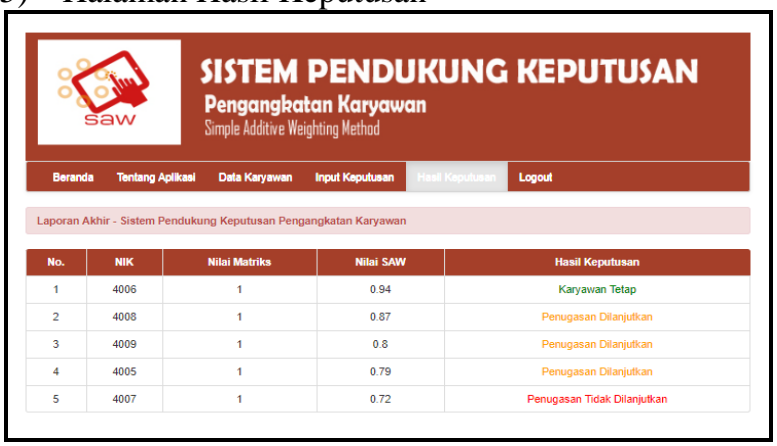

Sumber: Hasil Penelitian (2019)

Gambar 8. Halaman Hasil Keputusan

e. Pengujian

Pada penelitian ini dilakukan pengujian menggunakan black box testing, yang dapat dilihat pada tabel dibawah ini:

Tabel 6. Black Box Testing SPK Pengangkatan Karyawan Tetap

\begin{tabular}{|c|c|c|c|}
\hline Skenario & Test Case & Hasil & Kesimpulan \\
\hline $\begin{array}{l}\text { Pilih NIK dan } \\
\text { input matriks } \\
\text { kriteria }\end{array}$ & $\begin{array}{l}\text { NIK: diisi } \\
\text { Matriks } \\
\text { Kriteria: } \\
\text { diisi }\end{array}$ & $\begin{array}{l}\text { Sistem } \\
\text { menyimpan data } \\
\text { dan tampil } \\
\text { message "Data } \\
\text { Berhasil } \\
\text { Tersimpan!!" } \\
\text { kemudian } \\
\text { menampilkan } \\
\text { data matriks, } \\
\text { data normalisasi } \\
\text { dan hasil } \\
\text { keputusan yang } \\
\text { telah diinput. }\end{array}$ & Sukses \\
\hline $\begin{array}{l}\text { Pilih NIK } \\
\text { yang sudah } \\
\text { diinput } \\
\text { sebelumnya } \\
\text { dan input } \\
\text { matriks } \\
\text { kriteria }\end{array}$ & $\begin{array}{l}\text { NIK: diisi } \\
\text { Matriks } \\
\text { Kriteria: } \\
\text { diisi }\end{array}$ & $\begin{array}{lr}\text { Sistem } & \text { gagal } \\
\text { menyimpan data } \\
\text { dan } & \text { tampil } \\
\text { message } & \text { "NIK } \\
\text { yang } & \text { anda } \\
\text { masukan } & \text { sudah } \\
\text { ada" } & \end{array}$ & Sukses \\
\hline
\end{tabular}

Sumber: Hasil Penelitian (2019) 


\section{KESIMPULAN}

Berdasarkan uraian dan penjelasan mengenai penerapan metode simple additive weighting untuk menentukan pengangkatan karyawan memberikan hasil akhir penilaian berupa perangkingan sehingga dapat menentukan karyawan kontrak mana yang layak untuk diangkat menjadi karyawan tetap, karyawan yang dilanjutkan penugasannya untuk diberikan kesempatan memperbaiki kinerjanya dan penugasan tidak dilanjutkan. Penggunaan metode ini memberikan hasil keputusan sesuai dengan kebutuhan berdasarkan kriteria yang diperlukan dari perusahaan.

\section{REFERENSI}

Alinezhad, A., Amini, A., \& Alinezhad, A. (2009). Sensitivity analysis of simple additive weighting method (SAW): the results of change in the weight of one attribute on the final ranking of alternatives. Journal of Industrial Engineering, 4, 13-18.

Saepudin, M., Abdillah, G., \& Yuniarti, R. (2017). Sistem Pendukung Keputusan Menentukan Kelayakan Pengangkatan Karyawan Tetap Menggunakan Metode Analytic Hierarchy Process Dan, 43-48.

Sari, Y. K., Kartini, D., \& Muliadi. (2018). Implementasi Algoritma SAW ( Simple Additive Weighting ) Dempster Shafer Pada
Diagnosa Awal Postpartum Depression, 3(1), 16.

Turban, E., Aronson, J. E., \& Liang, T. (2007). Decision Support Systems and. New Delhi.

Wahyudi, S., Suheri, H., H, T. N., Komputer, S., Teknologi, F., \& Masalah, L. B. (2015). Implementasi Sistem Keputusan Pengangkatan Karyawan Tetap Pt . Imanuel Surya Utama Menggunakan Metode Saw, 2(1).

\section{PROFIL PENULIS}

Siti Ernawati, M.Kom. Kelahiran: Bogor, 08 Agustus 1990. Telah menyelesaikan pendidikan Strata I (S1) Program Studi Sistem Informasi di STMIK Nusa Mandiri Jakarta pada tahun 2012 dan pendidikan Strata II (S2) Program Studi Ilmu Komputer di STMIK Nusa Mandiri Jakarta pada tahun 2015.

Risa Wati, M.Kom. Kelahiran: Kotagajah, 15 Maret 1988. Telah menyelesaikan pendidikan Strata I (S1) Program Studi Sistem Informasi di STMIK Nusa Mandiri Jakarta pada tahun 2012 dan pendidikan Strata II (S2) Program Studi Ilmu Komputer di STMIK Nusa Mandiri Jakarta pada tahun 2015. 